\title{
The Technical and Business Analysis of Using Shore Power Connection in The Port of Hamburg
}

\author{
Devi Hotnauli Samosir ${ }^{1}$, M Markert ${ }^{2}$, and Wolfgang Busse ${ }^{2}$ \\ ${ }^{1}$ Department of Marine Engineering, Faculty of Marine Technology, \\ Institut Teknologi Sepuluh Nopember (ITS), Jl. Arief Rahman Hakim, Surabaya 60111 Indonesia \\ ${ }^{2}$ Surabaya and Hochschule Wismar, Rostock \\ e-mail: devisamosir@gmail.com, matthias.markert@hs-wismar.de,wolfgang.busse@hs-wismar.de
}

\begin{abstract}
In port, when the ship is berthing the loading, unloading, and hospitality activity is using auxiliary engine. The combustion of marine fuels is a major contributor to air pollution, the air pollution is released $400 \mathrm{~km}$ around the port area. The impacts of the pollution are respiratory, health, and the environment around ports. Study indicates 60.000 of cardiopulmonary mortalities caused by ship air emission. Ship emission represents $3 \%$ of global $\mathrm{CO}_{2}, 15 \%$ of global $\mathrm{NO}_{x}$, and $6 \%$ of global $\mathrm{SO}_{\mathrm{x}}$ emission. Because of that Hamburg Port is released the shore power facilities in July 2015 with idea of smart port and use the renewable energy such as wind turbine and solar panel compliance with IEC-ISO-IEEE 8005-1. In this bachelor thesis, the cost and also the condition between shore power and auxiliary engine will be analyzed and compared to find the most economical between shore power facilities and ship's auxiliary engine. Shore power facilities in Hamburg are provided by SIEMENS with SIHARBOR and use a robot arm by Stemman Technik as the cable management system. The goal of this thesis is developed calculation tool to see the cost comparison and also the emission. And from the calculation tool the shore power is reducing the emission by $100 \%$ because of using the renewable energy and become economical than using auxiliary engine, it can save up to $€ 1000$. The other benefits are ship owner can save maintenance of their auxiliary engine and also saved the file. It shows that the shore power is a proven technology to reduce the emission and saved berth cost.
\end{abstract}

Key Words - onshore power, Port of Hamburg, High Voltage Shore Connection

\section{INTRODUCTION}

S HIP traditionally not subject to emissions control, when

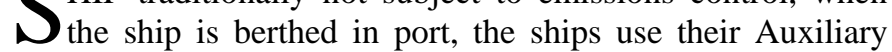
Engines (AE) to generate electrical power for loading unloading and hospitality activities (i.e. lights, airconditioning, the galleys, etc.). Ship emissions are one of the largest uncontrolled sources of pollutants. As a consequence, International Maritime Organization (IMO) was set-up the new environmental regulations at a global scale. In 2004, The MARPOL Convention (73/78), focused on minimizing pollution by ships and applies equally to every member state worldwide. Annex VI has placed limits on sulfur oxide (requiring use of $<4.5 \%$ sulfur fuel by 2010 , and its target is to reduce world maritime sulfur output to $<0.5 \%$ by 2020 ) and nitrogen oxide emissions from ship exhaust and prohibited deliberate emissions of ozone. In addition to Port State
Control, there are additional controls and penalties to ensure the compliance of the international standards.[1]

The problem of using diesel fuel is increasing carbon and nitrogen dioxide emissions. There are many opinions about using this cold ironing system in the ship company based on the diesel fuel price and the difference of berth cost using the shore power connection or diesel fuel. Nowadays, in Germany there are two ports that provide shore power connection facilities, that is Lübeck Port and Hamburg Port. The port of Hamburg just released the shore power facilities in July 2015 for the cruise ship to minimize a major source of air pollutant in the port area and make a clean energy supply

In this bachelor thesis will be discussed about the economical comparison between shore power connection with diesel fuel. And the result of this bachelor thesis is a decision making tool to choose the most economical between shore power connection with diesel fuel, and analyze the environmental benefit of shore power connection in Port of Hamburg.

\section{LITERATURE REVIEW}

\section{A. Potential Shore Power in Europe}

In US ports this is now mandatory and accordingly ships must be equipped with shore power equipment. The results of the evaluation of the theoretical maximum potential of Shore Side Electricity SSE in terms of GWh for the year 2020 are presented in Fig. 1 .If all seagoing ships in European harbors would use SSE by 2020 for covering their energy demand at berth, they would consume 3342 GWh annually (or 3543 GWh if we also consider inland shipping), which is approximately $0.1 \%$ of the electricity consumption in Europe as a whole in 2012. Fig. 1 also denotes the excessive energy demand of cruise ships while staying in-port due to their hospitality activities, as their annual electricity consumption in ports (i.e. $1334 \mathrm{GWh}$ ) represents $39.9 \%$ of the total. The energy requirements in terms of annual electricity consumption (GWh/a) for EU seaports in 2010 and 2020 have been estimated based on detailed analysis of the traffic in each port, and results are depicted in Fig. 2. The inland ports are not plotted because of their very low impact on the results (they potentially contribute to $6 \%$ of the total demand from SSE). As can be seen, similar geographical patterns appear between 2010 and 2020 with small anticipated increase in some areas.[2] 


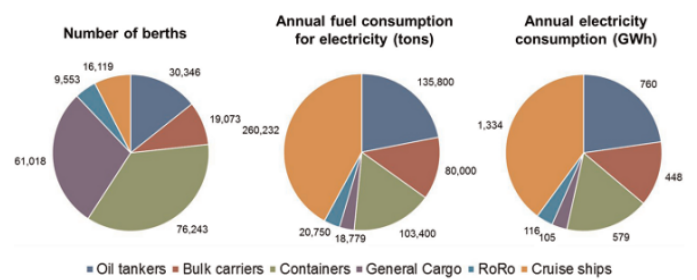

Figure 1. Maximum potential of SSE of ships at berth in EU ports for year 2020

Source : (R.Winkel, et al. 2015)

\section{B. Shore Power Supply}

Shore power supply or cold ironing is a process enabling a ship to turn off its engines while berthed and to plug into an onshore power source. The ship's power load is transferred to the shore-side power supply without a disruption of onboard services, but it is possible to have a disruption when the transfer is blackout. This process allows emergency equipment, refrigeration, cooling, heating, lighting, and other equipment to receive continuous electrical power while the ship loads or unloads its cargo. Cold Ironing is also known as shore Connection, On Shore Power Supply, High Voltage Shore Connection (HVSC).

The concept of plugging in a ship at port allows to shutting down diesel generators which can eliminate pollution from shipboard emissions. The source for shore power supply is provided by: grid power from an electric utility company, in port power plants, renewable energy resources.

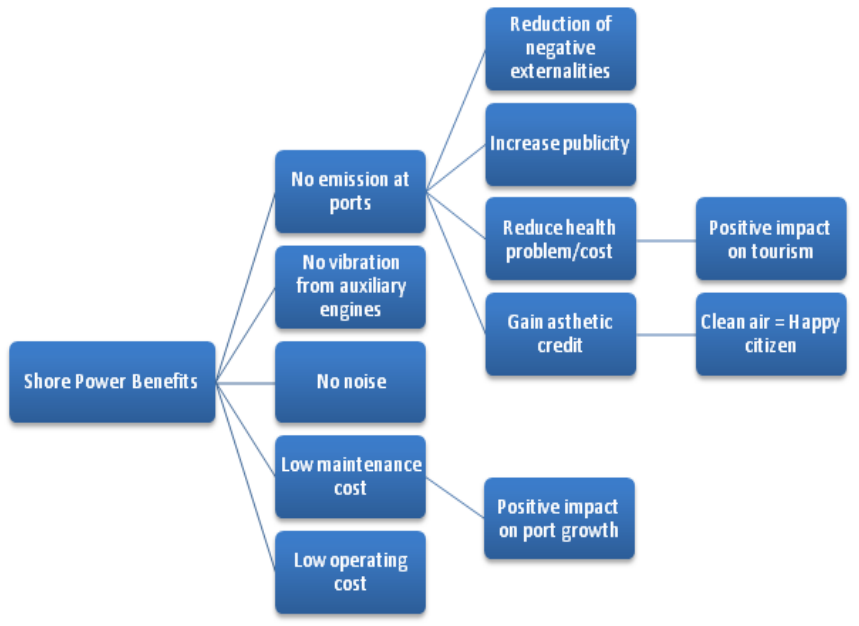

Figure 2. Shore Power Benefits

Source: Adapted from Altran 2008, p. 5. Tool Kit (Shore Power).

Shore Power Supply in the Port of Hamburg is using SIHARBOR. It is a shore-to-ship connection system developed by SIEMENS that includes all components which is necessary to supply ship from the local grid (see Figure 5.1-1). SIHARBOR in Altona has a $12 \mathrm{HVA}-10,0 \mathrm{kV}-60 \mathrm{~Hz}$, which can be transformed to the ship voltage and frequency. There are 4 steps to connect onshore power to the ship, first receive the power, then convert-adapt-separate, supply the power, and distribute on-board the ship. SIHARBOR comprises a variable frequency converter SINAMICS SM120 CM and mediumvoltage switchgear NXAir Used that is especially designed for shore connection system

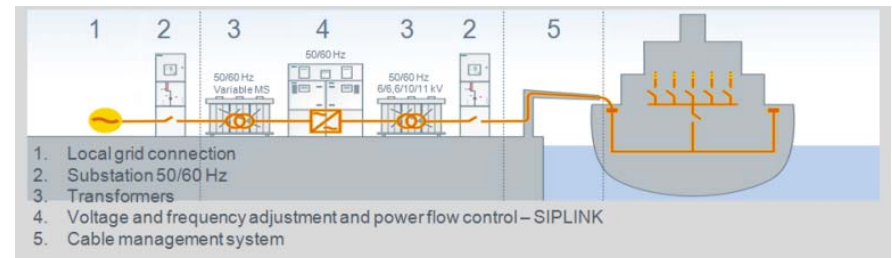

Figure 3. SIHARBOR by SIEMENS

The onshore power supply is using mobile carrier system up to 16 MW, which call a Robot arm. It is an efficient cable handling and connection from Stemmann Technik which can flexibly move from different positions and automatically compensate for tidal range compensation at 9 meters or 29 feet (see Figure 5.1-16). It is easy to control because it is self propelled and a motorized vehicle. The adjustable power voltage is from $6.6 \mathrm{kV}-11 \mathrm{kV}$. Protection class by IP67. The system is equipped with drive and hydraulic unit, $11 \mathrm{KV}$ connection box, deflection roller, telescopic plug holder system and differential drive. The tidal range can be compensated by a cable loop which are connected full time by stainless steel energy chain to the shore side switch gear without additional plugs and socket

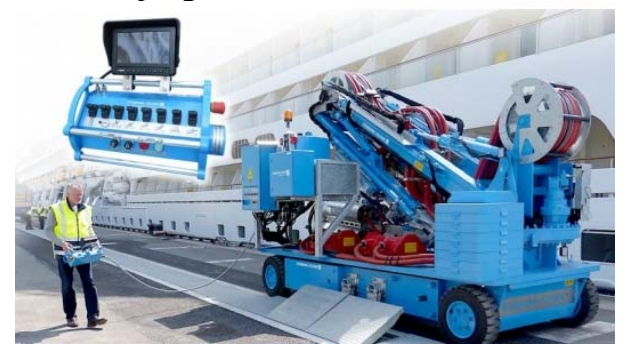

Figure 4. Cable management system using robot arm by Stemmann Technik

\section{Marine Diesel Fuel}

Marine diesel fuel is at the bottom of refinery process, and therefore rich in sulfur but low in price[3]. IMO requires to use fuels with a sulfur level no more than 35,000 parts per million (ppm) and after 2020 the sulfur level of marine diesel $<$ 5,000 ppm. The emissions intensity from marine diesel engines is pretty high. Therefore shore power supply offer a better solution for reducing the emission.

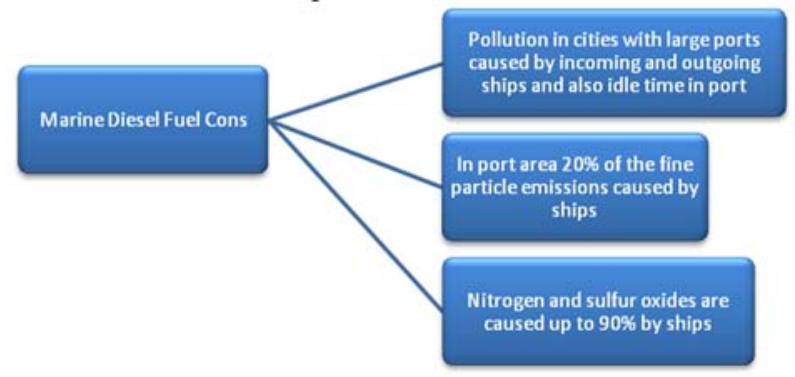

Figure 5. Marine Diesel Fuel Disadvantages

Source : $A B B$

\section{METHODOLOGY}

To solve the problem above, the five stages are divided as work processes for data collection and analysis, namely: 1. Statement of Problem 
This bachelor thesis begins by identifying the problems regarding to the case study in Hamburg Port with two conditions, shore power connection and auxiliary diesel engine.

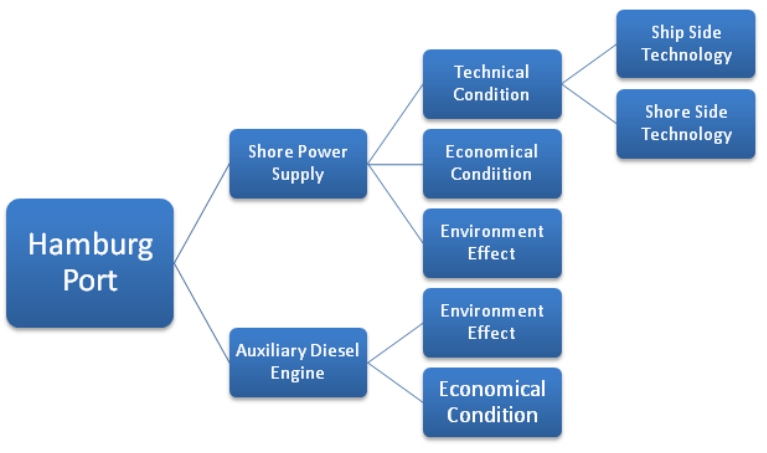

Figure 6. Study Case in Hamburg Port

2. Literature Study

3. Data Collection in Hamburg Port

Data required for this stage are:

a. Traffic and activity statistic of the ships

b. Existing shore power connection

c. Real cost of the electricity / day

d. Pollution data

e. Regulatory of Hamburg Port

f. Cost of fuel and lube price

4. Analysis and identify the economical difference

Table 1 Identify economical factor

\begin{tabular}{c|c|c|c|c}
\hline \hline $\begin{array}{c}\text { Ship's } \\
\text { name }\end{array}$ & $\begin{array}{c}\text { Times of } \\
\text { berth }\end{array}$ & $\begin{array}{c}\text { Berth Time } \\
\text { (hours) }\end{array}$ & $\begin{array}{c}\text { Electrical Power } \\
\text { Demand (kWh / day) }\end{array}$ & Price \\
\hline- & - & - & - & - \\
\hline \hline
\end{tabular}

Table 2 . Identify Environmental Effect

\begin{tabular}{|c|c|c|}
\hline "Auxiliary Diesel Engine & \multicolumn{2}{|c|}{ Shore Power Connection } \\
\hline- & \multicolumn{2}{|r|}{-} \\
\hline \multicolumn{3}{|c|}{ Table 3 Source emission of shore power connection } \\
\hline$\%$ & Sources & Pollution Unit \\
\hline - & - & - \\
\hline \multicolumn{2}{|c|}{ TOTAL EMISSION } & \\
\hline
\end{tabular}

\section{Decision Making Tool}

The decision making tool is a calculation to choose the most economical way between shore power connection and auxiliary diesel engine using Microsoft-Excel.

\begin{tabular}{|c|c|}
\hline \multicolumn{2}{|c|}{$\begin{array}{c}\text { Table 4Onshore Power Cost } \\
\text { OPERATIONAL COSTS }\end{array}$} \\
\hline INPUT & COSTS (€) \\
\hline \multicolumn{2}{|l|}{ Electricity price $(€ / \mathrm{kWh})$} \\
\hline \multicolumn{2}{|l|}{ Tax (€/ kWh) } \\
\hline \multicolumn{2}{|l|}{ Consumption (kW) } \\
\hline \multicolumn{2}{|l|}{ TOTAL COSTS (€) } \\
\hline \multicolumn{2}{|c|}{ Table 5 Onboard Cost } \\
\hline \multicolumn{2}{|c|}{ OPERATIONAL COSTS } \\
\hline INPUT & COSTS (€) \\
\hline \multicolumn{2}{|l|}{ Diesel (USD/ton) } \\
\hline \multicolumn{2}{|l|}{ Consumption (ton/h) } \\
\hline \multicolumn{2}{|l|}{ Emission Penalty } \\
\hline TOTAL COSTS (€) & \\
\hline
\end{tabular}

Table 6 Shore Power Supply Pollution Indicator

\begin{tabular}{|c|c|c|}
\hline \multicolumn{3}{|c|}{ POLLUTION } \\
\hline \multicolumn{2}{|c|}{ INPUT } & POLLUTION UNITS \\
\hline SOURCE & $\begin{array}{c}\text { (i.e coal, wind, } \\
\text { water) }\end{array}$ & \\
\hline Pollutants & Emissions & Pollution Units \\
\hline $\mathrm{CO} 2$ & - & - \\
\hline NOx & - & - \\
\hline PM & - & - \\
\hline $\mathrm{SO} 2$ & - & - \\
\hline & TOTAI & \\
\hline
\end{tabular}

\section{DATA ANALYSIS}

\section{A. Harbor-side Costs}

Hamburg port authority has released the port fees and charge 2016 which divide into some price category. The table below shows a summarize of cruise ship price in port in various factors.

Table 7. Port fees and charges

\begin{tabular}{|l|c|l|}
\hline \multicolumn{3}{|c|}{ Port Fees and Charges } \\
\hline Name & Price & Details \\
\hline Berth fees & $0,2384 € /$ GT & Port fees cover a period up to 120 hours \\
\hline Low season discount & $50 \%$ & October-November/January-March \\
\hline ESI discount & & $\begin{array}{l}\text { See ESI score discount at } \\
\text { http: } / / \text { wwww.environmentalshipindex.org } / \text { Public Ships }\end{array}$ \\
\hline ESI score $20-25$ & $0,5 \%$ & Maximally $€ 250$ \\
\hline ESI score $25-35$ & $1 \%$ & Maximally $€ 500$ \\
\hline ESI score $35-50$ & $5 \%$ & Maximally $€ 1000$ \\
\hline ESI score $\geq 50$ & $10 \%$ & Maximally $€ 1500$ \\
\hline Port power discount & $15 \%$ & Maximally $€ 2000$ \\
\hline
\end{tabular}

Table 8 Shore power fees and maintenance

Shore Power Fees and Maintenance MAINTENANCE

\begin{tabular}{|c|c|}
\hline Onshore power supply & $20.000 € /$ year \\
\hline \multicolumn{2}{|l|}{ FEES } \\
\hline Environmental tax & - \\
\hline Fees for electric power source $(€ / K W h)$ & $0,0005 € / \mathrm{kWh}$ \\
\hline Incentives for using shore power & $15 \%$ \\
\hline
\end{tabular}

\section{B. The Use of Harbor-side Electric Shore Power}

Table 9 shows the total pollution when using shore power and using onboard power. The HPA is declaring that the electricity source is from renewable sources (wind and solar panel) which reduced the $\mathrm{NO}_{\mathrm{x}}, \mathrm{SO}_{\mathrm{x}}, \mathrm{CO}^{2}$, and $\mathrm{PM}$. Even the ship is already using LSMGO with sulfur $<0,1 \%$ the emission is still exist.

\begin{tabular}{|c|c|c|c|}
\hline \multicolumn{4}{|c|}{ POLLUTION USING SHORE POWER } \\
\hline Electricity source & wind, solar panel & & \\
\hline Pollutants & Emmisions(ton) & Pollution units & TOTAL \\
\hline $\mathrm{CO}^{2}$ & 0 & & \multirow{4}{*}{0} \\
\hline Nox & 0 & 0 & \\
\hline $\mathrm{SO} 2$ & 0 & 0 & \\
\hline PM & 0 & 0 & \\
\hline \multicolumn{4}{|c|}{ POLLUTION USING ONBOARD POWER } \\
\hline Electricity source & LS MGO $(0,1 \%)$ & & \\
\hline Pollutants & Emmisions(ton) & Pollution units & TOTAL \\
\hline $\mathrm{CO}^{2}$ & 37,26 & & 1.090 \\
\hline
\end{tabular}




\begin{tabular}{r|r|r|}
\hline \hline N0x & 0,7506 & 750,6 \\
\hline SO2 & 0,02376 & 304,128 \\
\cline { 1 - 2 } PM & 0,0162 & 35,64 \\
\hline \hline
\end{tabular}

sure the safe cable connection. Then robot arm will connect the cable connection of HV-power cable and FO-cable. After connection the ship requires the shore to supply the power and the the ship is switching and synchronizing. The synchronization from ship will begin after all the onboard

\section{On-board Cost}

AIDA was one of participating ship list in WPCI, the AIDA ESI score is 21.5 to calculate the ESI

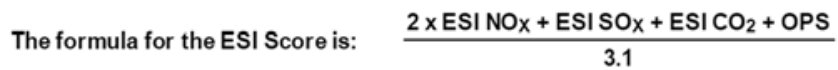

Because AIDA participating in WPCI, the vessel will get an extra discount while berthing (See APPENDIX 1) with ESI score 20 up to $<25=0.5 \%$ discount, maximally $€ 250$. When AIDA use shore power there will be a discount incentive 15\% with a maximal €2000. Table below will give a comparison when the vessel is not using the shore power. It makes a difference in the amount of $€ 1268$

Table 9. AIDAsol port fees using shore power

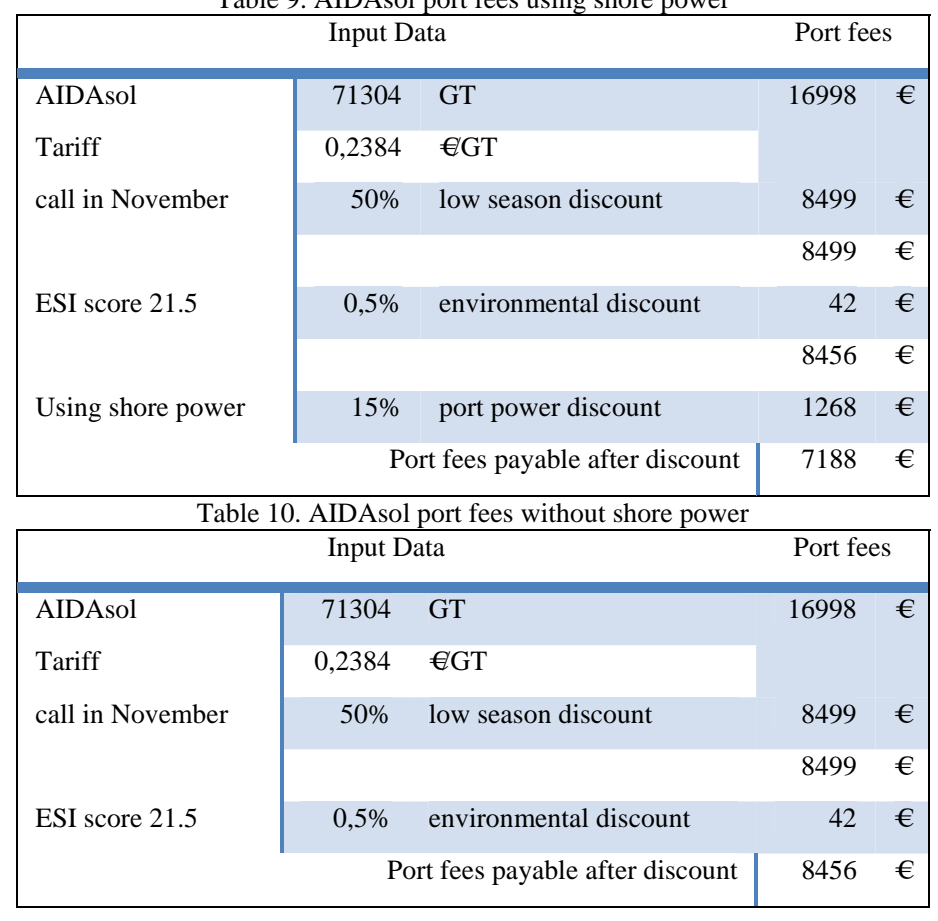

\section{On-board Conditions for Connection}

Cruise ship must install some equipment to make a connection to shore power supply as a transformer, cable connectors, short circuit protection, alarm, etc.

The main ship requirements from IEC /ISO/IEEE 80005-1 :
a. Shore connection switchboard
b. Circuit breaker, disconnector, earth switch
c. Transformer
d. Protection against electrical faults
e. Ship connection procedure
f. Ship power restoration
g. Load transfer

Time needed for installing the shore power to the ship is approximately 45 minutes. First to make a connection the ship shore connection has to be earthed and interlocked to make equipment is energized from the shore power except the synchronization switch, and when it is done the synchronization switch will close and shore power run in parallel with ship generator only for a short time. The diesel generator will unload, stop running and the generator switched off automatically.

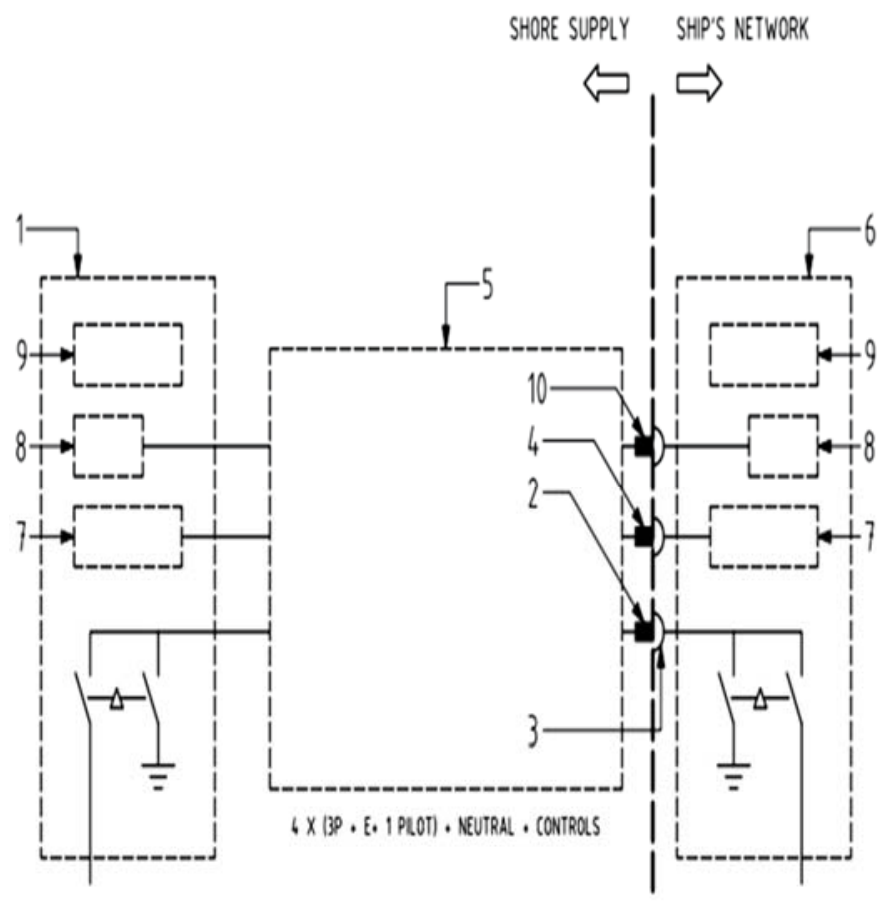

Figure 7. Block diagram of HVSC system arrangement on cruise ship

The IEC/ISO/IEEE 80005 describes HVSC systems, on board the ship and on shore, to supply the ship with electrical power from shore. A typical HVSC system described in this standard consists of hardware components as shown in Figure.1

1. A shore connection system can be supplied from national grid or port electrical system through a power frequency conversion

2. HV-plug as a connector that inserted into the ship's HV socket

3. Ship's HV-socket as a connecting point which drove the power towards the ship's network

4. Pilot wires which integrated with plug and socket to control the system

5. The cable management system as a connector to feed the power from shore to shore connection switchboard

6. The shore connection switchboard is provided with a shore power connecting circuit breaker with circuit protection devices 
7. Interlocks with pilot wire as a prevention of such disturbances

8. Communication for control and monitoring

9. Protective relaying to detect unbalance phase conductors, directional earth fault, current balance between cables in parallel

10. Communication and control wires

\section{E. Decision Making Tool}

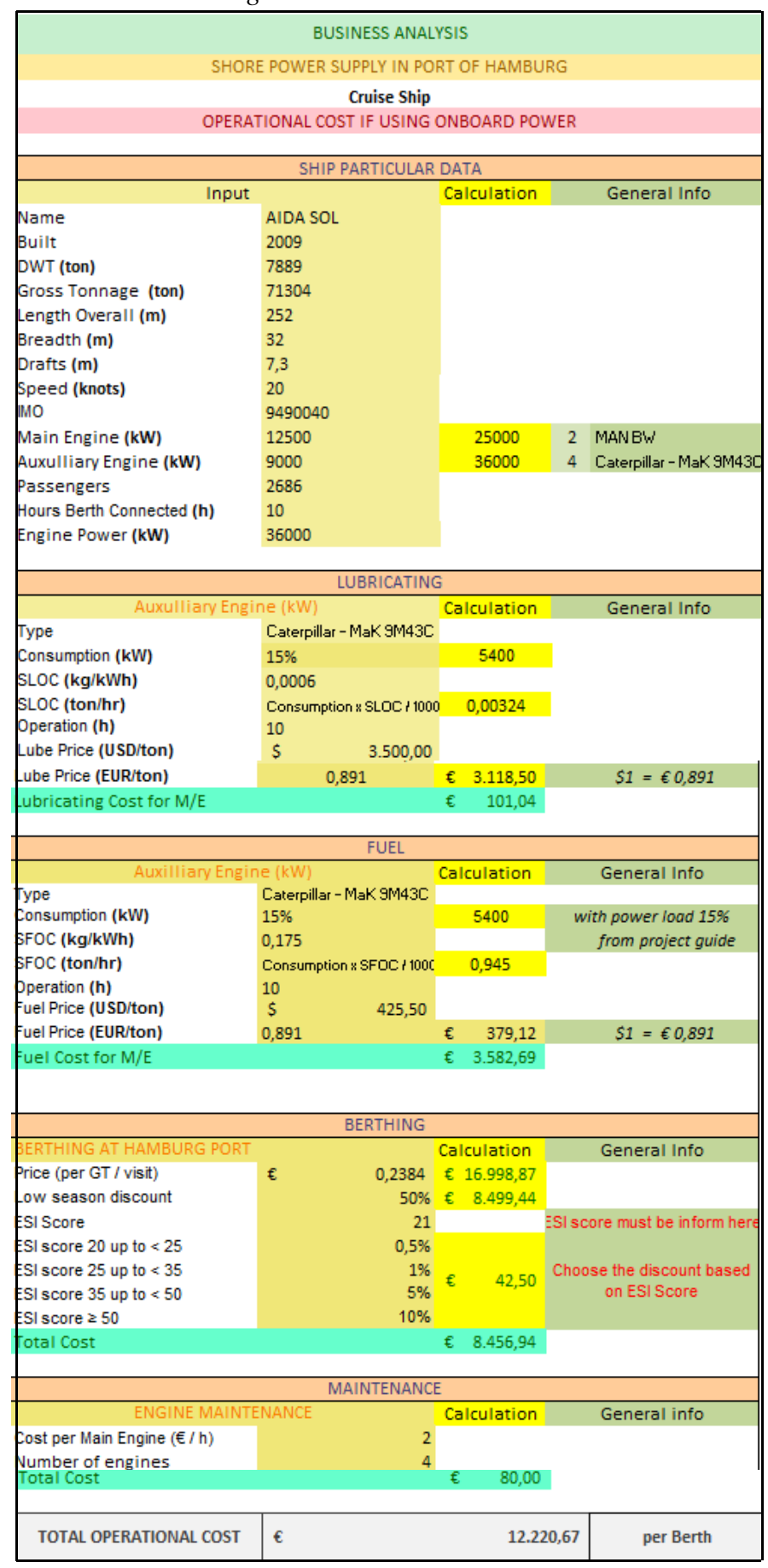

\begin{tabular}{|c|c|c|c|c|c|c|}
\hline \multicolumn{7}{|c|}{ BUSINESS ANALYSIS } \\
\hline \multicolumn{7}{|c|}{ SHORE POWER SUPPLY IN PORT OF HAMBURG } \\
\hline \multicolumn{7}{|c|}{ Cruise Ship } \\
\hline \multicolumn{7}{|c|}{ OPERATIONAL COST IF USING ONSHORE POWER } \\
\hline \multicolumn{7}{|c|}{ SHIP PARTICULAR DATA } \\
\hline \multicolumn{3}{|l|}{ Input } & \multicolumn{3}{|c|}{ Calculation } & General Info \\
\hline Name & \multicolumn{2}{|c|}{ AIDA SOL } & & & & \\
\hline Built & \multicolumn{2}{|c|}{2009} & & & & \\
\hline DWT (ton) & \multicolumn{2}{|c|}{7889} & & & & \\
\hline Gross Tonnage (ton) & \multicolumn{2}{|c|}{71304} & & & & \\
\hline Length Overall (m) & \multicolumn{2}{|c|}{252} & & & & \\
\hline Breadth $(\mathrm{m})$ & \multicolumn{2}{|c|}{32,2} & & & & \\
\hline Drafts $(\mathrm{m})$ & \multicolumn{2}{|c|}{7,3} & & & & \\
\hline Speed (knots) & \multicolumn{2}{|c|}{20} & & & & \\
\hline IMO & \multicolumn{2}{|c|}{9490040} & & & & \\
\hline Main Engine (kW) & \multicolumn{2}{|c|}{12500} & & 25000 & 2 & MANBW \\
\hline Auxulliary Engine (kW) & \multicolumn{2}{|c|}{9000} & & 36000 & 4 & Caterpillar - MaK 9M43C \\
\hline Passengers & \multicolumn{2}{|c|}{2686} & & & & \\
\hline Hours Berth Connected (h) & \multicolumn{2}{|c|}{10} & & & & \\
\hline Engine Power (kW) & \multicolumn{2}{|c|}{36000} & & & & \\
\hline \multicolumn{7}{|c|}{ ELECTRICITY } \\
\hline Electric Shore Power & & & & alculation & & General Info \\
\hline Price $(€ / \mathbf{k W h})$ & \multicolumn{2}{|c|}{0,0005} & & & & \\
\hline $\operatorname{Tax}(£ / \mathrm{kWh})$ & 19 & & & 0,000095 & & \\
\hline Consumption (kWh) & 540 & & & & & \\
\hline Operation (h) & 10 & & & & & \\
\hline Total Cost & & & $€$ & 32 & & \\
\hline & & BERTH & $\mathrm{HIN}$ & & & \\
\hline BERTHING AT HAMBL & RG P & & & alculation & & General Info \\
\hline Price (per GT / visit) & $€$ & 0,2384 & $€$ & $16.998,87$ & & \\
\hline Low season discount & & $50 \%$ & $€$ & $8.499,44$ & & \\
\hline ESI score & & 21 & & & & I score must be inform here \\
\hline ESI score 20 up to $<25$ & & $0,5 \%$ & & & & \\
\hline ESI score 25 up to $<35$ & & $1 \%$ & & & & hoose the discount based \\
\hline ESI score 35 up to $<50$ & & $5 \%$ & $€$ & 42,50 & & on ESI Score \\
\hline ESI score $\geq 50$ & & $10 \%$ & & & & \\
\hline After ESI score Discount & & & $€$ & $8.456,94$ & & \\
\hline Port power discount & & $15 \%$ & $\varepsilon$ & $1.268,54$ & & \\
\hline Total Cost & & & $€$ & $7.188,40$ & & \\
\hline & & ED SHIP M & MAIN & ITENANCE & & \\
\hline ENGINE MAINTEN & $\overline{A N C}$ & & & alculation & & General info \\
\hline Cost per Main Engine $(€ / \mathrm{h})$ & & -2 & & & & \\
\hline Number of engines & & 4 & & & & \\
\hline Total Cost & & & $-\varepsilon$ & 80,00 & & \\
\hline TOTAL OPERATIONAL COST & $€$ & & & 7.140 , &, 53 & per Berth \\
\hline
\end{tabular}

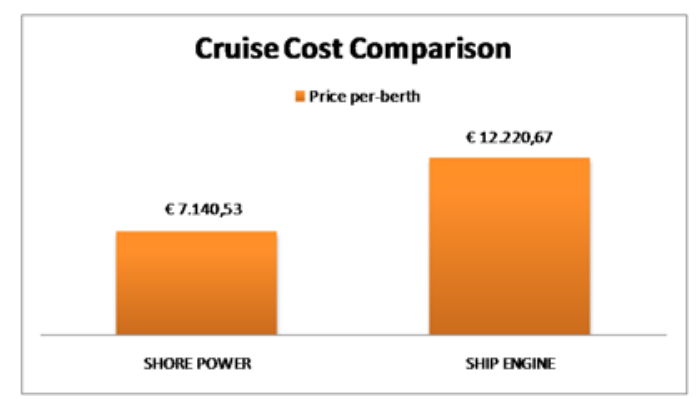

\section{Assumptions}

For the purpose of this thesis, the following assumptions were made in calculating the data collected and estimations made:

a. Electricity generated from Port of Hamburg is believed to be from environmentally friendly resources such as wind turbine and solar panel

b. Only calculate the operational cost to find the cheapest cost between shore power and ship engine 
c. All ships which use in calculation tools have the shore power facilities on board and ready to connect to shore power

d. Cost for electric shore power is 0,5€/MWh (Martechnic Hamburg 2015)

e. Cost for lubricating oil is $3500 \$$ ton (alibaba.com)

f. The port fees are using port price list 2016 , published by the Hamburg Port Authority

g. Cost of maintenance €1.6/hour (Jiven, 2004)

h. Type of fuel is used LSMGO $0,1 \%$ because Hamburg is in ECA area

\section{General Formula}

a. The following general formula is used for cost calculation:

b. Lube cost $€=\left(\frac{\text { Power Consumption }(k W) \times \operatorname{SLOC}\left(\frac{\mathrm{kg}}{\mathrm{kWh}}\right)}{1000}\right) \times$ Operation time $(h) \times$ lube price $\left(\frac{\epsilon}{\text { ton }}\right)$

c. Fuel cost $€=\left(\frac{\text { Power Consumption }(\mathrm{kW}) \times \operatorname{SFOC}\left(\frac{\mathrm{kg}}{\mathrm{kWh}}\right)}{1000}\right) \times$ Operation time $(h) \times$ fuel price $\left(\frac{\epsilon}{\text { ton }}\right)$

d. $\quad$ Maintenance cost $=€ 1.6 /$ running hour (Jiven, 2004)

e. Shore power cost $=$

f. Consumption $(k W) \times$ Operation time $(h) \times$ Electrical price $\left(\frac{€}{k W h}\right)$

g. The following general formula is used for emission calculation:

h. Emission (ton) $=$ operation time $(h) \times$ consumption $(k W) \times$ emission factor $\left(\frac{g}{k W h}\right)$ 1000000

i. $\quad$ Pollution unit $=$ Emission $($ ton $) \times$ emission equivalent $\left(\frac{\text { pollution }}{\mathrm{kg}}\right) \times 1000$

j. $\quad$ Total Cost $=$

k. SOx pollution unit + NOx pollution unit + PM pollution unit

1. Emission reduction electricity $(\%)=$

m. $1-\left(\frac{\mathrm{CO} 2 \text { emission from shore power }}{\mathrm{CO2} \text { emission from onboard power }}\right)$

\section{CONCLUSION}

When the ship is cruising in ECA area they must use fuel oil within $0.1 \%$ sulfur content below or have EGCS (Exhaust Gas Cleaning Systems). And the low sulfur fuel is more expensive. Shore power is becoming the best solution to save the operational cost while berthing at port. This thesis analyzes the technical condition of shore power in Terminal Altona, Hamburg which is using the system standards IEC/ISO/IEEE 80005-1. Hamburg is commissioned SIEMENS to build a SIHARBOR which has a capacity of $12 \mathrm{HVA}, 11 \mathrm{kV}$ and 60 $\mathrm{Hz}$. And Stemmann Technik provides the robot arm as a cable management for connecting the cable from shore to ship and can flexibly move from different positions and automatically compensate for tidal range compensation at 9 meters or 29 feet (see Figure 5.1-16). From the calculation tool which developed in this bachelor thesis, it shows that shore power is way cheaper than an auxiliary diesel engine it can save up to $9000 €$ with using some limitation (See Table 6-1). The impact when using the auxiliary diesel engine are:

a. High emission caused human health impacts

b. High cost for fuel

c. Need an additional scrubber to reduce emission

d. Noise and vibration from engine

e. Need an additional cost for engine maintenance

f. Climate impact because of air pollution caused by combustion fuel

The benefit when using shore power :

a. Cut the emission moreover, while using the renewable source and environmentally friendly (see Table 6-4) which is reducing emission to $100 \%$.

b. Get a $15 \%$ discount of using shore power on port fees

c. No noise and vibration

d. Healthy environment

e. Easy to connect due to the technology of robot arm

f. Saved maintenance cost for auxiliary engine

From the result of analyzing shore power facility in Hamburg it can be concluded that this facility is not a proven technology because its still need to be improved from the shore side of Altona Terminal. In the other side this facility is using a renewable energy and reduce the total cost when ship is berthed. So the ship owner can choose the shore power facilities as the cheapest than using diesel engines, and port can make a green port concept because using an environmentally friendly electric sources.

\section{REFERENCES}

CNSS, The challenge of emission control in maritime law, (n.d.). Ecofys, Potential for Shore Side Electricity in Europe Potential for Shore Side Electricity in Europe, (2013). H. Wang, X. Mao, D. Rutherford, Costs and Benefits of Shore Power At the Port of Shenzhen, (2015). 